\title{
THE IMPORTANCE OF APPRAISAL AND PROFESSIONAL ASSOCIATION FOR CREATIVE ECONOMY BUSINESS ACTORS
}

\author{
Uswatun Hasanah $^{1 *}$, Hardianty Munawir ${ }^{2 *}$
}

\begin{tabular}{l}
\hline * Affiliation: \\
${ }^{1}$ Department of Foreign \\
language and Literature, \\
National Sun Yat-sen \\
University, Taiwan \\
Email: \\
uswahs9@gmail.com \\
${ }^{2}$ Regional Secretariat, \\
Central Buton Regency, \\
South East Sulawesi, \\
Indonesia \\
email: \\
hardiantymunawir@gmail. \\
com.
\end{tabular}
com.

\begin{abstract}
:
In the era of globalization and technological advances, the development of creative economy is moving rapidly and offering much more different career for economic actors. But, this development of creative economy has some problems. The examples are the fluctuation of $c a s h$ flow on the creative economy business actors and wealth authority which belong to intangible assets. Thus, it is difficult to determine the average price of a work from creative economic actors.

According to the library researches, this study found the things that can solve the problem of a work standarization price for creative economy business actors. The creative economy business actors can be called as freelancer. They can make appraisal program under protection of professional association as policy maker and law protector to protect the value of a work from creative economy business actors.

keywords: Creative Economy Business Actors, Appraisal, Professional Association
\end{abstract}

\section{INTRODUCTION}

The structure of world economy transformed rapidly as the growth of economy. It started from natural resource base until human resource base, from genetic and extractive era to manufacture and information service era, until the last one goes to creative economy era. Creative economy is one of economy concept in the era of new intensive economical knowledge in the information and creativity from the human resources as the main production factors in economics programs.

Right after the end of 2015, Indonesia was welcoming the implementation of free market in Southeast Asia, called ASEAN Economic Community (AEC). Indonesia is expected to grab the benefit of AEC implementation. One of them is in the creative economy sector which have big potential to be one of the activator sector to catch the opportunity in AEC. Nowadays, creative economy is developing together with the development of technological information. It creates new creative industry based on local culture and knowledge. 
Creative economy is not only about the creation of added value on economy, but also in the creation of added value on the social, cultural, and surrounding. Creative industry, which belongs to subsystem of creative economy, becomes the activator in creating the values. In the year of 2000, creative economy sector contributes Rp.468,1 billion, 7,29\% from PDB national, through 14 sub-sectors in creative industry. They includes architecture, design, fashion, film, video, photography, handicraft, informational technology and software, music, art market, publisher, advertisement, interactive game, research and development, art performance, television, and radio.

According to the data from Badan Pusat Statistik, Indonesia in 2013 produced Rp.9.109.129,4 PDB (Produk Domestik Bruto). The number increased from 2012 that is only Rp.8.241.864,3. The ratio of PDB in 2012 and 2013 indicate 10,52 \% growth. All of those number was getting from the price of 10 economy sectors in Indonesia. While, creative economy sector contribute Rp.641.815,4 from total Rp.9.109.129,2. This contribution puts creative economy sector in ranking 7 from 10 economics sectors with percentage up to $7.05 \%$.

Unfortunately, there are many kinds of problem in creative economy sector. The examples are the regulation and enforcement of law, wealth intellectual authority which is used to protect individual creativity and certify the development of creative industry, appreciation of work, brand, and etc. In addition, plagiarism becomes a phenomenon which can be easily found nowadays, and another one is the understanding and awareness of the importance of knowledge.

\section{METHODOLOGY}

This paper is conducted by using library research. In this research, the writers use descriptive analysis method. Descriptive analysis is one of method by collecting, classifying, analyzing, and interpreting the data of references related to to the study.

\section{FINDING AND DISCUSSION}

\section{Creative economy business actors}

Dr. Richard Florida from the United States, the author of The Rise of the Creative Class and Cities and the Creative Class states

"All human beings are creative, whether he is a worker in a factory glass or a homeless youth who is making hip-hop. But the difference is the status (class), because there are individuals who specifically deal with a creative field and receive direct economic benefits from such activities. Then place them in the cities that are able to create new innovative products as the fastest, it can be confirmed as the winner in this era of creative economy."

From the statements of Dr. Richard, it refers to the notion of a freelance creative individual or economy business agent as the person who deals with any creative field where he does not bound by corporate or government bureaucracy. Nowadays, in the era of Internet and information technology, support from freelance profession is strongly important so that future creative economy industry will meet the right agent or actor to be creative worker.

First impression being a freelancer in Indonesia is often underestimated because it is considered less prestigious and it does not provide sufficient social security such as health and 
financial insurance. However, as the development of technology, especially the Internet and social media, professional freelancer such as graphic design, web developer, content writer, and others are slowly starting to get the recognition from society. More people in Indonesia begin to try new kind of profession such as being a freelancer.

\section{Payment mechanism for freelancer}

Working as a freelancer requires the upcoming clients to sign a written contract that will help to make sure the job mechanism. However it is not a must. The other way may perform work based on verbal agreements, which can be implemented through the types of the job. Some freelancers may provide written estimation fee of the works' service so that they can ask for an upfront payment from their clients.

Payment for freelance workers also varies. Freelancers may charge their clients in a matter per day, per hour, per page, or per-project basis. Instead of a flat rate or a fee, some casual workers have adopted the method of "value-based price" based on the perception of the value they generate for clients. With the change itself, payment arrangements can be upfront, percentage upfront, or after completion of the work or contract.

However, the payment methodis not standardized yet. It can cause a case of payment becomes not in accordance with the quality of one's work. This is what should be the concern of economic actors and the government. They need to realize that creative economy is not only a matter of copyright and plagiarism but also standardize the fee of a work. At least, a minimun fee per hour for freelancer is standardized so that both the client will know how much to pay and freelancer will know how much they will get paid. Furthermore,the detail for fee for each kind of work canbe formulated by the expert.

\section{Appraisal and benefits for creative economy business actors}

Appraisal is basically an estimation or opinion which is supported by specific reason or rational analysis. The feasibility of an assessment is limited by the availability of sufficient data, as well as the capability and objectivity of the appraiser. The assessment process of determining the value of a work is based on the goal to analyze, to interpret and to express it in an estimation of specific value. From the definition above, appraisal is clearly defined that an assessment of the intangible asset such as creative economy business actor is very important and needed. It can be a benchmark in standardizing the financial value of a work.

This case is a kind of one more task for government to create a concept of assessment that can be used as a benchmark or appraisal standardize the price of a work. It takes expert macroeconomists and creative economy business actors to formulate an appraisal program that can be a reference. The importance of steps to make such appraisal analysis and appreciate the price of a work will assist creative economy business actors in determining the price. It will be normal because basically government has the authority to standardize the price of works.

\section{Professional association for creative economy business actors}

The importance of an appraisal program would not be possible without any assessment and amercement. This is the reason why a professional association for creative economy 
business actor is needed.The importance of an appraisal program would not be possible without any assessment and amercement. This is the reason why a professional association for creative economy business actor is needed. Professional association has a protection function to its member. In addition, the association can give more value towards the performance of the workers.

Having a relevant professional association will help the freelancer in some aspects, not only in the job opportunity but also the quality of the jobs itself. Nowadays, no one can succeed only by relying on his own ability and luck. People need to work with other parties to help each other. Moreover, professional association can be place to share and to find solution for the problems that exist in the field. New information and knowledge related with the profession will be easier to get.

A professional association can develop and advance the profession. It can also monitor and expand the field of professional motion, collect and provide the opportunity for all members to work and to play an active role in developing and advancing the profession. Nowadays, with the development of globalization, professional must be able to establish interaction with other professional from many other countries. Through their professional organizations, more economic interactions will occur.

In another way, professional association can provide some benefits to the creative economy business actors such as determining an implementation standard of professional certification. A certification is one of the symbol of a professionalism.

By having a certificate that is recognized nationally and internationally, people will see a high level of professionalism from the certificate holder. This can provide a certain level for creative economy business actors. In addition, professional association can establish professional ethics policies to be followed by all members and issue the price of standardization policies through assessment. They can also formulate assessment procedures so that creative economy business agents can standardize the prices of their works.

\section{CONCLUSION}

Every profession needs to have a value of appreciation. This must be in accordance with the work carried out by creative economy business actors. It is important for them to accept and to have clear job authority. It is their right to obtain appropriate value for the work they have done. They need legal protection and recognition from the work or the profession. This means that the existence of an appreciation value or assessment program can be used as a standard for creative economy business actors. Moreover, it can also be used to measure the quality of the actors. The importance of professional association is that one can work professionally as a medium of self-development and standards in carrying out the job profession. 


\section{Reference}

Banker. 2014. AlasanPerlunyaPenilaianKinerja (Performance

Appraisal).http://bankernote. com. Accessed in December 4, 2016.

Blake, Roberto. 2016. The Impact of the Gig Economy on Design Jobs. http://www.howdesign. com. Accessed in December 4, 2016.

Efendi, Syahrul. 2015. EkonomiKreatif: Permasalahan, TantangandanProspeknya. http:// www.kompasiana.com. Accessed in December 5, 2016.

Gandini, Alessandro .2015. Digital Work Self-Branding And Social Capital in The Freelance Knowledge Economy. Marketing Theory SAGE Journals.

Hakim, Lukman. 2015. MenangkapGelombangEkonomiKreatif Indonesia di Era MEA. https:// www.selasar.com. Accessed in December 4, 2016.

Howkins, John, (2001), The Creative Economy: How People Make Money From Ideas, Penguin Book, England.

Kemal, Prita. 2014. PeranOrganisasiProfesi. http://www.lspr.edu. Accessed in December 4, 2016.

Markusen, Ann, et Al. 2008. Defining the Creative Economy: Industry and Occupational Approaches.Economic Development Quarterly Jorunal vol. 22 no.1 24-45

Pratt, AC and P Jaffcut. 2009. Creativity, Innovation and the Cultural Economy. Taylor and Francis e-Library : Madison Avenue, New York.

Richard Florida (2001) dalambukunya "The Rise of Creative Class dandalam Cities and the Creative Class"..Harvard University Press.

Storey, John, et Al. 2005. Living With Enterprise in an Enterprise Economy: Freelance and Contract Workers in The Media. Human Relations SAGE Journals vol. 58 no. 8 1033- 1054.

Unknown.2015. Salah KaprahEkonomiKreatif Indonesia.http://motulz.com. Accessed in December 4, 2016. 